\title{
HUZALOS SZIKRAFORGÁCSOLÁSSAL MEGMUNKÁLT SZERSZÁMACÉLOK FELÜLETMINŐSÉGI VIZSGÁLATAI
}

\section{INVESTIGATIONS OF SURFACE QUALITIES OF WIRE EDM MACHINED TOOL STEELS}

\author{
Tóth László
}

Óbudai Egyetem, Bánki Donát Gépész és Biztonságtechnikai Mérnöki Kar, Budapest, Magyarország, toth.laszlo@bgk.uni-obuda.hu

\begin{abstract}
In the EDM process an electrical discharge occurs between an anode (graphite or copper) and a cathode (material to be machined) in a dielectric medium. Developments in EDM technologies have opened a new path towards high-precision, more productive machining of high alloyed, high hardness and high strength steels [1]. Wire EDM offers an efficient and cost effective alternative to traditional machining in tool and component manufacturing [2]. EDM machining removes electrically conductive material with rapid and repetitive spark emissions using a dielectric fluid. As a result, the surface of the raw material is subject to erosion. The quality of the machined surface depends to a large extent on the parameters of the machining technology [3]. In the testing experiments, wire EDM machining was performed on two tool steel grades using different machining parameters. After each machining step, hardness and roughness tests were performed on the surface of the workpiece. Scanning electron microscopy was performed on the machined surface. The tests confirmed that the surface quality of the tools is significantly influenced by the parameters set during the EDM. The change of parameters was achieved by performing multiple cutting threads. By using the multiple cutting thread, tools with favorable surface roughness have been produced for tool steels with a high hardness of quenched and tempered heat treatment state.
\end{abstract}

Keywords: wire EDM, tool steel, surface roughness, scanning electron microscopy.

\section{Összefoglalás}

A szikraforgácsolással történő megmunkálás során elektromos kisülés következik be egy anód (grafit- vagy rézelektróda, illetve rézhuzal) és egy katód (megmunkálandó anyag, szerszámacél) között dielektromos közegben. A szikraforgácsolási (elektroeróziós) technológiák fejlesztései új utat nyitottak az erősen ötvözött, nagy keménységű és nagy szilárdságú acélok nagy pontosságú, termelékenyebb megmunkálási irányába [1]. A huzalos szikraforgácsolás hatékony és gazdaságos alternatívát ajánl a hagyományos megmunkálásokkal szemben a szerszám- és alkatrészgyártásban [2]. A szikraforgácsolással történő megmunkálások gyors és ismétlődő szikrakibocsátásokkal távolítják el az elektromosan vezető anyagot, dielektromos folyadék segítségével. Ennek következtében az alapanyag felülete eróziónak van kitéve. A forgácsolt felület minősége nagymértékben függ a megmunkálási technológia paramétereitől [3].

A vizsgálati kísérleteim során két szerszámacél minőségen huzalos szikraforgácsolási megmunkálásokat végeztem különböző technológiai paramétereket használva. Minden megmunkálás után a munkadarab felületén keménységi és érdességi vizsgálatokat végeztem. A megmunkált felületen pásztázó elektronmikroszkópos vizsgálatokat hajtottam végre. A vizsgálatok alátámasztották, hogy a szerszámok felületi minőségét jelentősen befolyásolják a szikraforgácsolási technológia során beállított paraméterek. A paraméterek változtatását többszörös vágási menetek elvégzésével értem el. A többszörös vágási menet alkalmazásával a nagy keménységű, edzett-megeresztett hőkezelési állapotú szerszámacélok esetében sikerült kedvező felületi érdességű szerszámokat legyártani.

Kulcsszavak: huzalos szikraforgácsolás, szerszámacél, felületi érdesség, pásztázó elektronmikroszkóp. 


\section{Bevezetés}

Az acélok szikraforgácsolási technológiával történő megmunkálásának nagy előnye az is, hogy nagy keménységü, bonyolult geometriájú munkadarabok is könnyen előállíthatók [4]. Huzalos szikraforgácsolásnál a huzalelektróda és a munkadarab között ívkisülés megy végbe, melynek során a munkadarabból az anyagfelesleg elgőzölög. A munkadarab legkülső rétege elérheti az $50000^{\circ} \mathrm{C}$-ot is, itt az acél megolvad és elpárolog, az olvadt fémcseppeket a dielektrikum öblíti. Az elektromos kisülésekkel történő anyagleválasztás legfőbb paraméterei az áramerősség, a kiszikrázási idő $\left(\mathrm{t}_{\mathrm{on}}\right)$ és a szünetidő $\left(\mathrm{t}_{\mathrm{off}}\right)$. A kiszikrázási idő $\left(t_{o n}\right)$ és a szünetidő $\left(t_{\text {off }}\right)$ összege a periódusidő [5]. A kiszikrázási idő növelésével növeljük a periódus kitöltési tényezőjét, így nagyobb áramerősséget kapunk, a sebesség jelentősen növekedhet. Hosszabb szikrázási fázisok hatása mélyebb erodálást eredményez, és a szikraköz megnövekszik. A szünetidőnek a stabilitásban van fontos szerepe, hosszabb idő alatt több idő jut a leválasztott anyag öblítésére, valamint a közeg és munkadarab hűtésére. A felületi minőséget a frekvencia is befolyásolja, nagyobb frekvencia jobb felületi minőséget eredményez. Összességében a megmunkálás akkor lesz gazdaságos, ha minél kevesebb idő alatt minél jobb felületi minőségű kész darabot gyártunk.

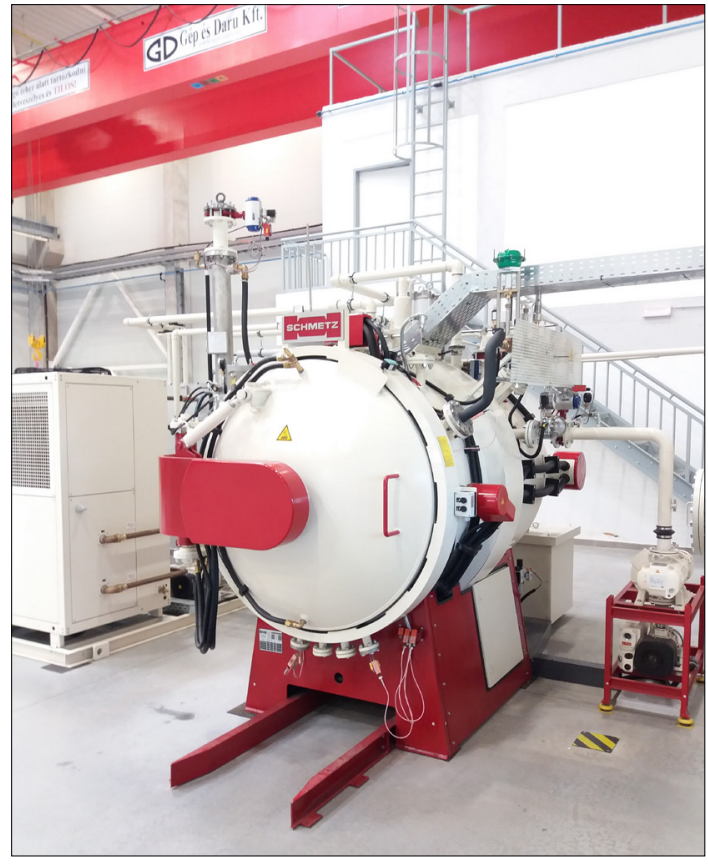

1. ábra. Schmetz-vákuumkemence
A gyakorlati szikraforgácsolási technológiák során megkülönböztetünk nagyoló és simító vágásokat. A vágások számával az áramerősség egyre csökken, a frekvencia egyre nő. A szikraforgácsolás nagy érdeme a pontosság, viszont nem megfelelő megmunkálási paraméterek használata a munkadarab felületén rétegződési hibákat, mikrorepedéseket, ötvözőelem-kiégéseket és ún. fehér réteget eredményezhet. Ezek a felületi hibák a technológia során képződött magas hőmérséklet hatására keletkezhetnek. A magas hőmérséklet elkerülhető többszörös vágások alkalmazásával csökkentett kisülési energiával.

Jelen tanulmányban a felületi minőség változását vizsgáltam kétféle szerszámanyag-minőség esetében, többszörös huzalszikra-forgácsolási eljárás hatására. A vizsgálatokkal edzett és megeresztett hőkezelési állapotú gyorsacél (Böhler S600) és hidegalakító szerszámacél (Böhler K110) felületi minőségét hasonlítottam össze többszörös vágások során.

\section{Vizsgálati anyagok és technológiák}

A vizsgált $\mathrm{S} 600$ és K110 minőségű acélmintadarabok vegyi összetétele az 1 . táblázatban látható.

A próbadarabok edzését és megeresztéseit egy Schmetz-típusú, 600×600×400 mm-es méretű vákuumkemencében (1. ábra) végeztem kétlépcsős hevítéssel $\left(650^{\circ} \mathrm{C}\right.$, illetve $\left.850^{\circ} \mathrm{C}\right)$. Az edzést 9,5 bar nyomású nitrogéngázzal végeztem.

Az edzést - szintén a vákuumkemencében - háromszori magas hőmérsékletű megeresztés követte (2.a. és 2.b. ábra).

A hőkezelési művelet után Rockwell C keménységmérést végeztem egy AVK gyártmányú KV-1 típusú gépen. A mért keménységi értékek a 2. táblázatban láthatók.

1. táblázat. Vizsgálati anyagok kémiai összetétele spektrométeres mérés alapján (tömeg $\%$-ban)

\begin{tabular}{|c|c|c|c|c|c|c|c|}
\hline Acél & C & Si & Mn & Cr & Mo & V & W \\
\hline K110 & 1,57 & 0,28 & 0,32 & 11,41 & 0,76 & 0,78 & - \\
\hline S600 & 1,38 & 0,57 & 0,29 & 4,14 & - & & 5,92 \\
\hline
\end{tabular}

2. táblázat. Hőkezelés utáni keménységek

\begin{tabular}{|c|c|}
\hline Acél & HRC \\
\hline K110 & 61 \\
\hline S600 & 64 \\
\hline
\end{tabular}




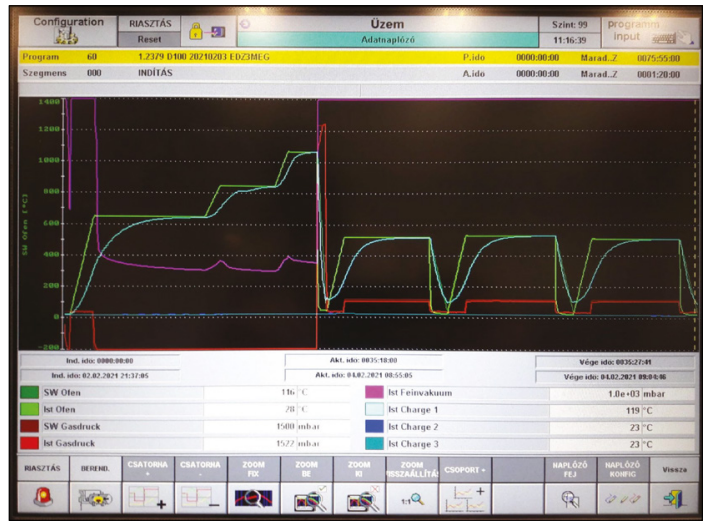

2.a. ábra. K110-es acél hökezelési diagramja

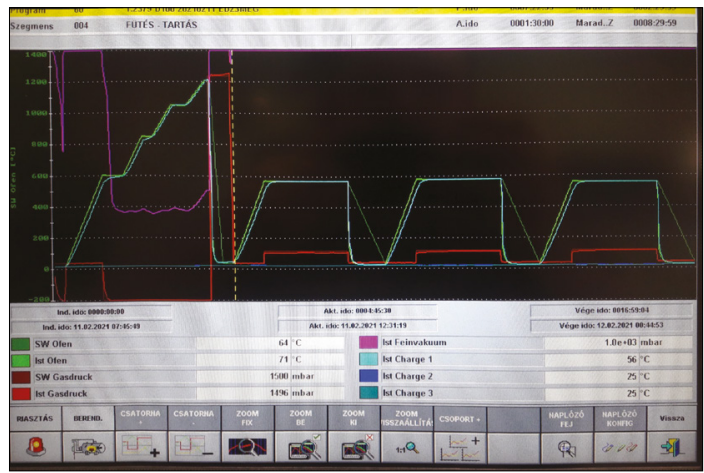

2.b. ábra. S600-as acél hökezelési diagramja

A hőkezeléseket a huzalos szikraforgácsolási megmunkálások követték, erre a célra egy 350x220x200 mm-es munkaterű, Charmilles FI240 SLP típusú szikraforgácsoló gépet használtam (3. ábra).

A gépi adatokat és a kívánt megmunkálási paramétereket a Charmilless FI 240 SLP gép 4. ábrán látható kezelőfelületén lehet beállítani.

A vágás során 0,25 mm-es átmérőjű elektrolitréz huzalt használtam, és dielektrikumként ionmentesített vizet.

A többszörös vágások során alkalmazott megmunkálási paramétereket a 3. táblázat ábrázolja.

A megmunkált darabokon felületiérdesség-méréseket végeztem, melynek során vizsgáltam:

- az általános felületi érdességet $\left(R_{a}\right)$, mely a valóságos profil és a középvonal közötti távolság abszolút értékének a számtani átlaga:

$R_{a}=\frac{1}{l} \int_{0}^{l}|Z(x)| d x$

- az egyenetlenségmagasságot $\left(R_{z}\right)$, mely a vizsgált hosszon az öt legnagyobb értékü hegycsúcs

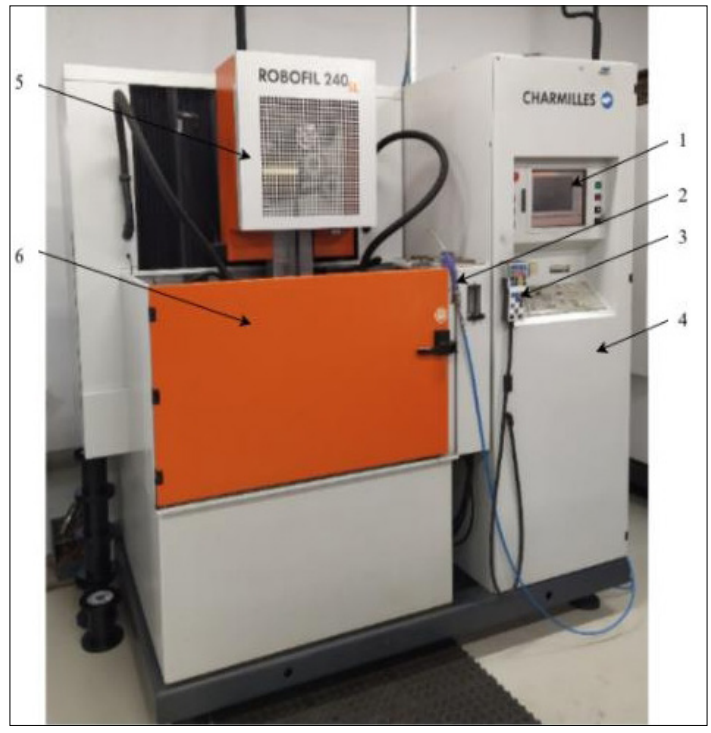

3. ábra. Charmilles FI240 típusú szikraforgácsoló gép 1. kezelö és megfigyelő terület, 2. levegőfúvóka, 3. huzalfej-tájoló egység, 4. generátortér, 5. huzaladagoló berendezés, 6. munkatér

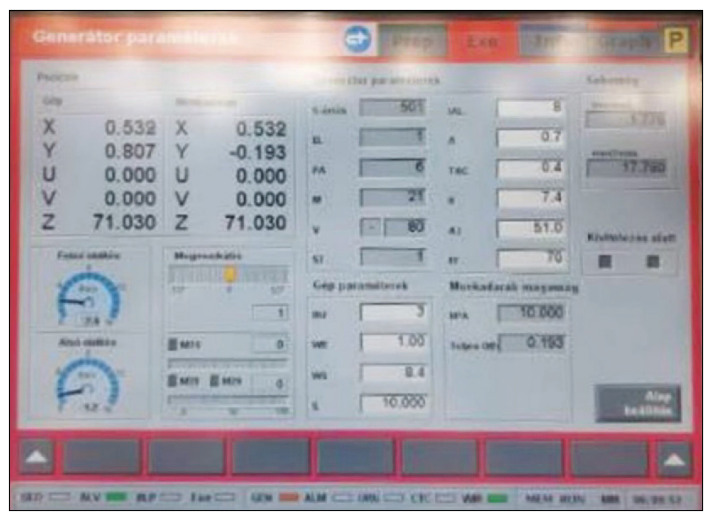

4. ábra. Charmilles gép kezelöfelülete

3. táblázat. Megmunkálási paraméterek

\begin{tabular}{|l|c|c|c|c|}
\hline Vágáslépések & $\begin{array}{c}\text { Áram } \\
(\mathbf{A})\end{array}$ & $\begin{array}{c}\text { Szikra- } \\
\text { idő } \\
(\boldsymbol{\mu s})\end{array}$ & $\begin{array}{c}\text { Szünet- } \\
\text { idő } \\
(\boldsymbol{\mu s})\end{array}$ & $\begin{array}{c}\text { Teljes } \\
\text { offset } \\
(\mathbf{m m})\end{array}$ \\
\hline Nagyolás & 21 & 0,7 & 7,4 & 0,12 \\
\hline Simítás 1 & 23 & 0,2 & 3,8 & 0,13 \\
\hline Simítás 2 & 7 & 0,4 & 3 & 0,13 \\
\hline Simítás 3 & 7 & 0,4 & 3 & 0,13 \\
\hline Simítás 4 & 7 & 0,2 & 3 & 0,13 \\
\hline Simítás 5 & 7 & 0,2 & 3 & 0,13 \\
\hline
\end{tabular}


és a legalacsonyabb értékű völgy különbségének a számtani átlaga:

$$
R_{z}=\frac{1}{n}\left(\sum_{i=1}^{5} p_{i}-\sum_{i=1}^{5} v_{i}\right) \text {. }
$$

Az érdesség mérésére a MahrSurf GD120 típusú érdességmérő gépet használtam (5. ábra).

Az elektronmikroszkópos vizsgálatot egy JSM 5310 típusú Jeol pásztázó elektronmikroszkópon végeztem (6. ábra).

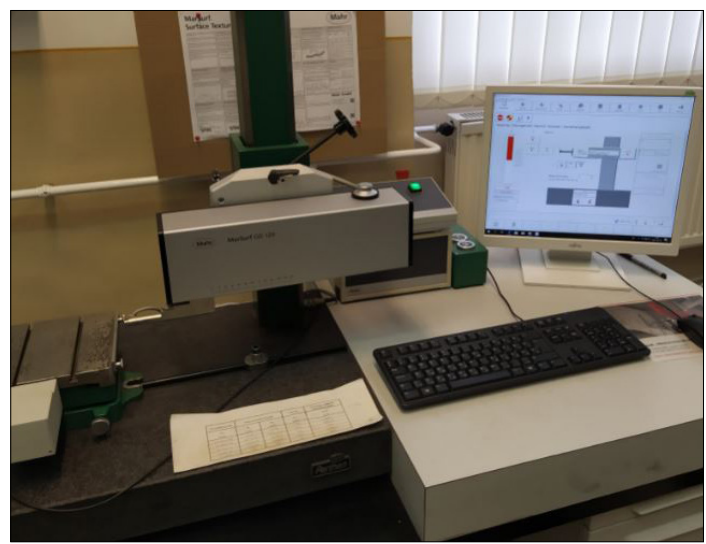

5. ábra. MahrSurf GD120 érdességmérő gép

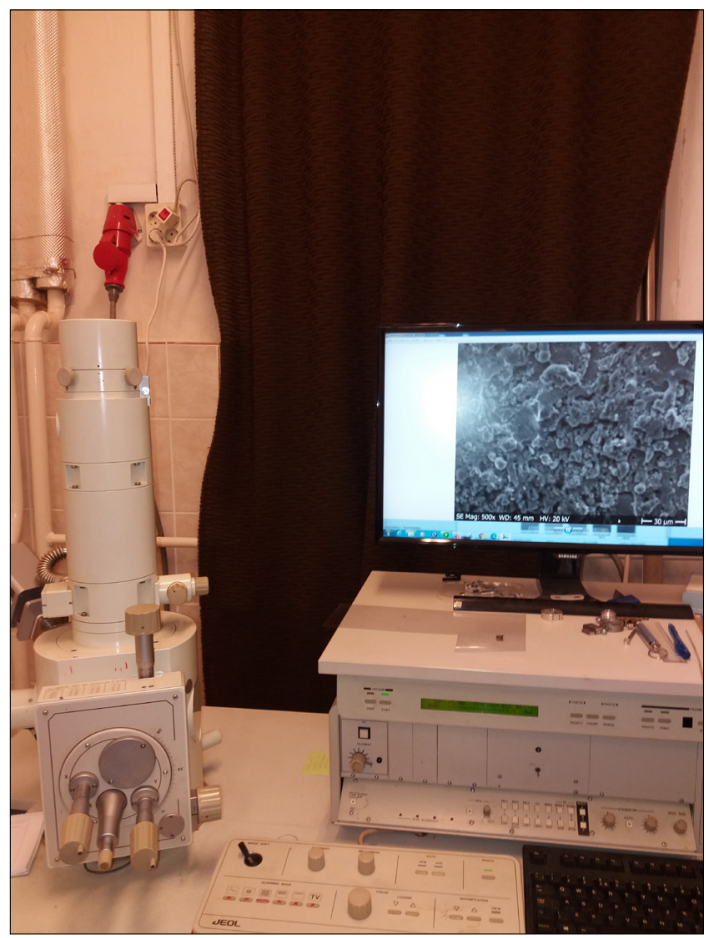

6. ábra. Jeol JSM5310 pásztázó elektronmikroszkóp

\section{Mérési eredmények}

\section{1. Érdességmérések}

Különböző simítások után a felületi érdesség mért értékei a K110-es hidegalakító szerszámacélra vonatkozóan a 4. táblázatban láthatóak.

A mért felületi érdesség értékei azt mutatják, hogy a Böhler K110-es edzett és háromszor megeresztett szerszámacél huzalos szikraforgácsolással történő nagyolási és egy simítási művelet utáni átlagos felületi érdessége meghaladja a $2 \mu \mathrm{m}$-t., míg az egyenetlenségmagasság értéke a 12,2 $\mu \mathrm{m}$-t. A következő simítások után ezek az értékek fokozatosan csökkennek, és az ötödik simítás után a felületi érdesség már $0,53 \mu \mathrm{m}$-re, míg az egyenetlenségmagasság 4,12-re csökken.

A Böhler S600-as minőségű gyorsacél különböző simítások utáni felületi érdességeit az 5. táblázat szemlélteti.

A mért felületi érdesség értékei azt mutatják, hogy a Böhler S600-as edzett és háromszor megeresztett gyorsacél huzalos szikraforgácsolással történő nagyolási és egy simítási művelet utáni átlagos felületi érdessége meghaladja a 2,5 $\mu \mathrm{m}$-t, míg az egyenetlenségmagasság értéke a 15,8 $\mu \mathrm{m}$-t. A következő simítások után ezek az értékek fokozatosan csökkennek, és az ötödik simítás után a felületi érdesség már 0,56 $\mu$ m-re, míg az egyenetlenségmagasság 3,98-ra csökken.

4. táblázat. K110-es acél érdességi értékei

\begin{tabular}{|l|c|c|}
\hline & $\mathbf{R a}(\boldsymbol{\mu m})$ & $\mathbf{R z}(\boldsymbol{\mu m})$ \\
\hline Simítás 1 & 2,14 & 12,28 \\
\hline Simítás 2 & 1,93 & 11,92 \\
\hline Simítás 3 & 1,06 & 7,44 \\
\hline Simítás 4 & 0,77 & 5,71 \\
\hline Simítás 5 & 0,53 & 4,12 \\
\hline
\end{tabular}

5. táblázat. S600-as acél érdességi értékei

\begin{tabular}{|l|c|c|}
\hline & $\mathbf{R a}(\boldsymbol{\mu m})$ & $\mathbf{R z}(\boldsymbol{\mu m})$ \\
\hline Simítás 1 & 2,58 & 15,83 \\
\hline Simítás 2 & 1,09 & 8,51 \\
\hline Simítás 3 & 1,09 & 7,69 \\
\hline Simítás 4 & 0,68 & 4,93 \\
\hline Simítás 5 & 0,56 & 3,98 \\
\hline
\end{tabular}




\subsection{Pásztázó elektronmikroszkópos vizsgá- latok}

A Böhler K110 és Böhler S600-as minőségű szerszámacélok huzalos szikrázással történő megmunkálásai után a vizsgálati darabok felületi minőségét pásztázó elektronmikroszkóp segítségével vizsgáltam.

A 7. ábrán a K110-es hidegalakító szerszámacél huzalos szikraforgácsolással megmunkált felülete látható 500-szoros nagyításban, az első simítás után. Továbbá ezen felület elektrodiszperzív spektrométeres (EDS) elemzése is látható.

A 8. ábrán a K110-es hidegalakító szerszámacél huzalos szikraforgácsolással megmunkált felülete látható 500-szoros nagyításban az ötödik simítás után. Továbbá ezen felület elektrodiszperzív spektrométeres (EDS) elemzése is látható.

A 9. ábrán az S600-as gyorsacél huzalos szikraforgácsolással megmunkált felülete látható 500-szoros nagyításban, az első simítás után. Továbbá ezen felület elektrodiszperzív spektrométeres (EDS) elemzése is látható.

A 10. ábrán az S600-as gyorsacél huzalos szikraforgácsolással megmunkált felülete látható 500-szoros nagyításban az ötödik simítás után. Továbbá ezen felület elektrodiszperzív spektrométeres (EDS) elemzése is látható.
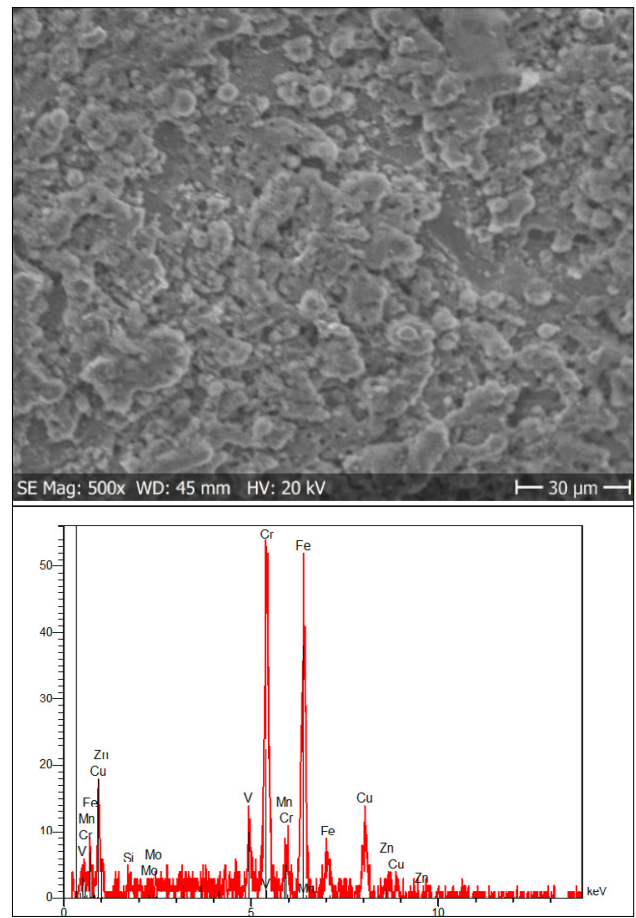

7. ábra. K110-es acél SEM-es képe az első simítás után 500x nagyításban
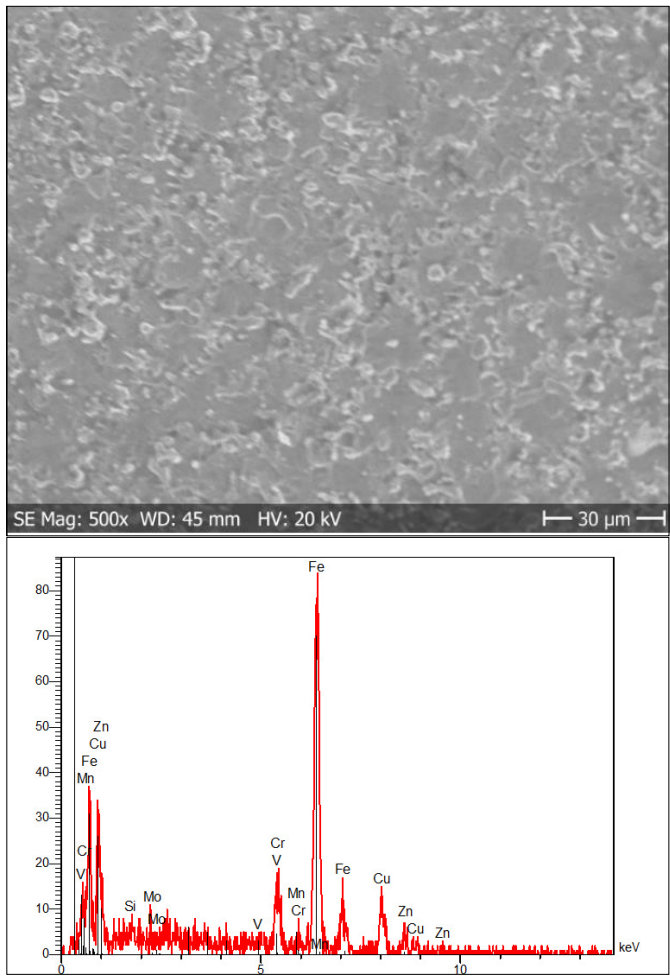

8. ábra. K110-es acél SEM-es képe 500x nagyitásban az ötödik simítás után
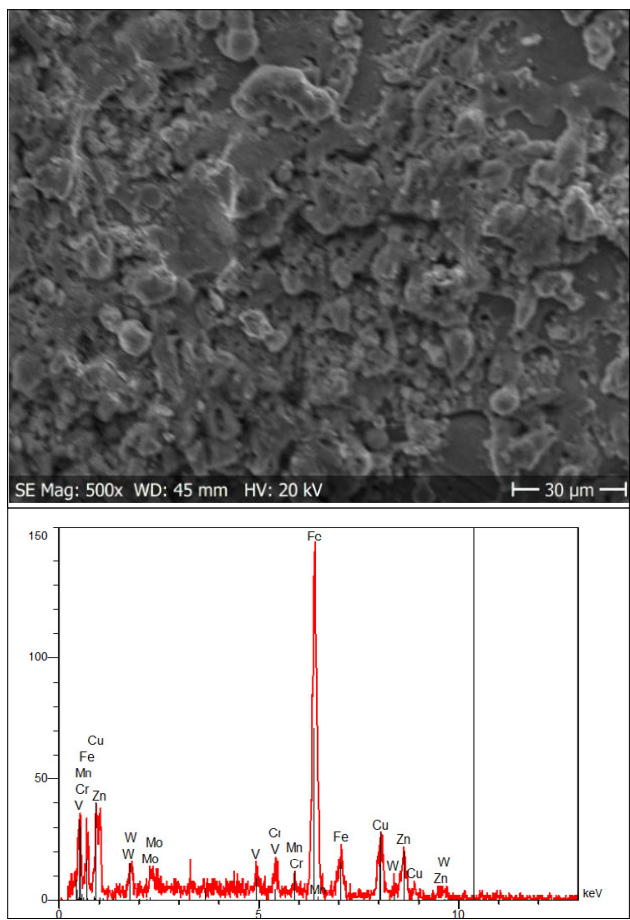

9. ábra. S600-as acél SEM-es képe az első simitás után 500x nagyításban 


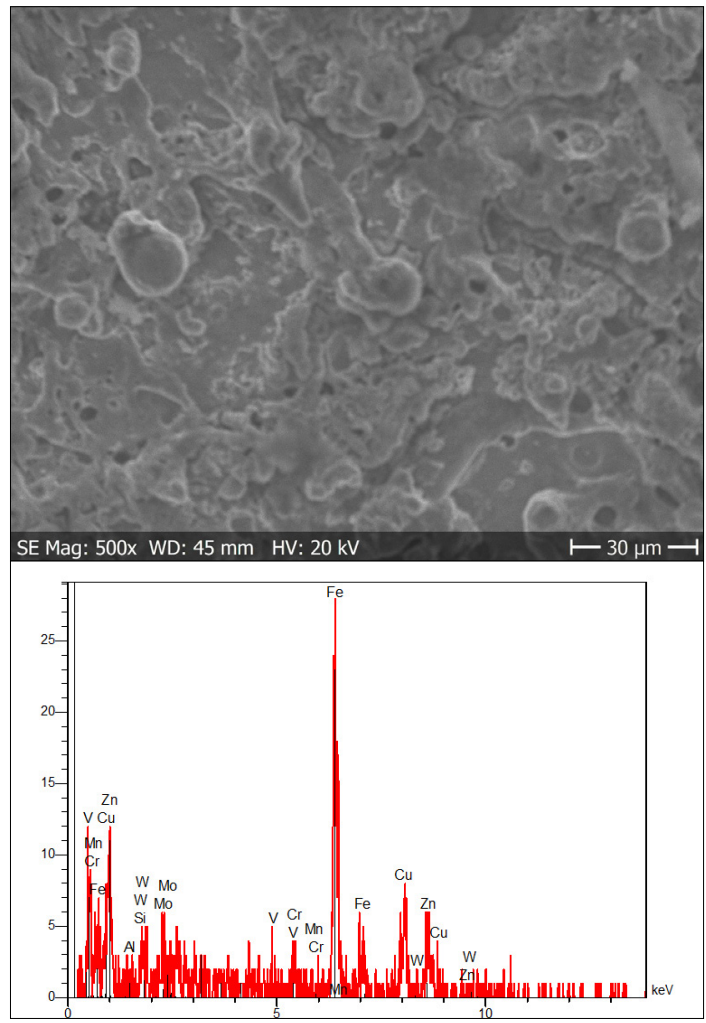

10. ábra. S600-as acél SEM-es képe 500x nagyításban az ötödik simítás után

\section{Következtetések}

A kísérleti vizsgálatok a huzalos szikraforgácsolási eljárással megmunkált szerszámacélok felületi rétegeiben történt változásokra összpontosultak. A nagy hőbevitel hatására képződött magas hőmérséklet következtében, az elektromos kisülések révén a felületen kráteres textúra képződött, mely elég jól látható a pásztázó elektronmikroszkóp első simításos felvételein. Az ötödik simítás után a kráteres textúra mértéke elhanyagolható.

A vizsgált felület elektrodiszperzív spektrométeres (EDS) elemzése alapján a K110-es acél esetében megfigyelhető az első simítás után a felületen lévő króm és vas nagy mennyisége, a vanádium és molibdén jelenléte, valamint valamennyi réz és cink. Az ötödik simítás után változnak egyes elemek koncentrációi, éspedig a króm csökken, míg a réz mennyisége nő. Ez annak tulajdonítható, hogy valamennyi króm kiégett a felületből, és a huzalelektródából réz olvadt a felületre.

Az S600-as acél esetében az első simítás után megfigyelhető a volfrám, molibdén, króm és va- nádium, valamint egy kevés réz és cink jelenléte a megmunkált felületen. Az ötödik simítás után itt viszont csak a réz és cink mennyisége nő, a többi ötvöző nem változik számottevően.

A felületiérdesség-vizsgálatok alapján egyértelműen megállapítható, hogy a simítások hatására egyre finomabb, kevésbé érdes felületet kapunk, de ez nem azt jelenti, hogy hatékony minél több simítást végezni.

A gyakorlatban az elvárt felületi érdességet a szerszám, illetve alkatrész felhasználása, illeszkedése határozza meg. A felületen képződött ún. „fehér réteget”, a krátereket, a beégett réz-, illetve cinkmaradványokat általában finom csiszolással vagy/és polírozással tüntetik el.

A kísérlet alapján, az elvárt felületi minőség függvényében meghatározható a simítási megmunkálások száma a vizsgált szerszámacélokra vonatkozóan.

\section{Köszönetnyilvánítás:}

A szerzők ezúton kívánnak köszönetet mondani a munkánkhoz nyújtott anyagi támogatásért - a EFOP3.6.1-16-2016-00010 számú projekt keretében - a magyar államnak és az Európai Uniónak.

\section{Szakirodalmi hivatkozások}

[1] Swiercz R., Oniszczuk-Sweiercz D.: Experimental Investigation of Surface Layer Properties of High ThermalConductivity Tool Steel after Electrical Discharge Machining. Metals, 7/12. (2017) 550. https://doi.org/10.3390/met7120550

[2] Sudhakova D. D., Prasanthi G.: Application of Taguchi Method for Determining Optimum Surface Roughness in Wire Electric Discharge Machining of P/M Cold Worked Tool Steel (Vanadis -4E). Procedia Engineering, 97. (2014) 1565-1576.

https://doi.org/10.1016/j.proeng.2014.12.440

[3] Guu Y. H., Hocheng H., Chou C. Y., Deng C. S.: Effect of Electrical Discharge Machining on Surface Characteristics and Machining Damage of AISI D2 Tool Steel. Materials Science and Engineering, 358/1-2. (2003) 37-43.

https://doi.org/10.1016/S0921-5093(03)00272-7

[4] Gokler M. I., Ozanogzu A. M.: Experimental investigation of effects of cutting parameters on surface roughness in the WEDM process. International Journal of Machine Tools and Manufacture, 40/13. (2000), 1834-1848.

https://doi.org/10.1016/S0890-6955(00)00035-3

[5] Jahan M. P.: Electrical Discharge Machining, Types Technologies and Applications. Nova Science Publishers, New York, 2015, 1-17. 